\title{
Gambaran Pengetahuan Remaja Puteri Terhadap Nyeri Haid (Dismenore) dan Cara Penanggulangannya
}

\author{
Erlina Rustam
}

\begin{abstract}
Abstrak
Dismenore merupakan gangguan menstruasi yang sering terjadi pada remaja putri. Untuk mengobatinya penderita cendrung menggunakan tindakan Farmakologi dan non Farmakologi. Telah dilakukan penelitian tentang gambaran pengetahuan dan cara menanggulangi dismenore pada remaja putri mahasiswi STIFARM Padang angkatan 2013 dengan jumlah responden 56 orang. Penelitian ini bersifat deskriptif dengan pengambilan data dilakukan dengan menggunakan kuesioner dan disajikan dalam bentuk tabel. Parameter yang digunakan adalah pengetahuan tentang menstruasi, dismenore dan tindakan yang dilakukan ketika mengalami dismenore. Dari penelitian didapat hasil yang tinggi dari pengetahuan remaja putri mengenai pengertian, lama dan penyebab menstruasi, pengetahuan yang rendah tentang siklus dan hormon yang berperan dalam menstruasi. Mempunyai pengetahuan yang tinggi terhadap dismenore seperti pengertian dismenore, usia yang sering mengalami dismenore, derajat dan penyebab dismenore. Tindakan yang dilakukan untuk mengatasi dismenore adalah tindakan non farmakologi (17,86\%). Secara Farmakologi remaja putri menggunakan obat tradisional daun sirih (67,00\%), Sedangkan yang memilih obat jadi adalah OJ-2 (40,00\%). Efek samping obat yang dirasakan adalah mengantuk $(56,52 \%)$. Alasan pemilihan obat adalah karena cepat menghilangkan nyeri (97,83\%). Disarankan untuk melakukan penyuluhan tentang cara pengobatan dismenore baik secara Farmakologi maupun nonfarmakologi.
\end{abstract}

Kata kunci: Dismenore, pengetahuan, pengobatan

\begin{abstract}
Dysmenorrhea is the most common gynecologic health problem presented among female adolescents. To treat this condition, patients tend to either use pharmacologic or non farmacologic treatments available. $A$ research had been done on the description of knowledge and how to over come a dysmenorrhea in female students of STIFARM Padang with sample 56 students. This is a descriptive study with data collection is done by using a questionnaire and presented in tabular form. The parameters used are knowledge about menstruation, dysmenorrhea and action taken when having dysmenorrhea. From the research concludet knowledge of the understanding, the time and the cause of menstruation, low knowledge about the cycle and hormones involved in menstruation. Have a good knowledge of the dysmenorrhea like deffenition of dysmenorrhea, the age who often get dysmenorrhea, the degree and cause of dysmenorrhea. The main action taken is non-pharmacological measures (17.86\%). In Pharmacology female adolescents using traditional medicine is a betel leaf (67.00\%). While choosing a drug is OJ-2 (40.00\%). Side effects are felt sleepy (56.52\%). The reason is because the choosen drugs can relief pain faster (97.83\%). It is suggested that educating people on the proper way to treat dysmenorrhea by Pharmacologic or nonpharmacologic treatment.
\end{abstract}

Keywords: Dysmenorrhea, knowledge,therapy

Affiliasi penulis : Bagian Farmakologi dan Terapi FK Universitas Andalas Padang

Korespondensi : Erlina Rustam, email: erlina_rustam@yahoo.com, Telp: 081363066205

\section{PENDAHULUAN}

Kesehatan perempuan merupakan topik yang penting dan tak ada habisnya untuk dibahas. Tingkat kesehatan perempuan, mencerminkan tingkat 
pelayanan kesehatan di suatu negara, bila angka kematian ibu masih tinggi berarti tingkat pelayanan kesehatan pun belum baik, sehingga apa pun yang terkait dengan kesehatan perempuan selalu menjadi siklus pembahasan yang tidak ada habis-habisnya, salah satunya adalah haid pada perempuan. ${ }^{1}$

Haid atau menstruasi adalah pengeluaran darah dan sel sel tubuh dari vagina yang berasal dari dinding rahim perempuan secara periodik. Defenisi lain bisa juga diartikan sebagai siklus alami yang terjadi secara regular untuk mempersiapkan tubuh perempuan setiap bulannya. Rata-rata masa haid perempuan 3-8 hari dengan siklus rata-rata 28 hari pada setiap bulannya. Dan batas maksimal masa haid adalah 15 hari. Selama darah yang keluar belum melewati batas tersebut, maka darah yang keluar adalah darah haid. ${ }^{2}$

Biasanya menstruasi diawali pada usia remaja 9-12 tahun. ada sebahagian perempuan yang mengalami haid lebih lambat dari itu (13-15 tahun). Kondisi remaja yang sudah mengalami haid secara emosional tidak stabil. Sebahagian dapat juga menimbulkan gejala-gejala seperti pegal pada bagian paha, sakit pada daerah payudara, lelah, mudah tersinggung, kehilangan keseimbangan, ceroboh dan gangguan tidur, bahkan pada sebahagian perempuan ada yang mengalami rasa sakit saat haid yang disebut dengan dismenore. ${ }^{1}$

Dismenore adalah kondisi medis yang terjadi sewaktu haid atau menstruasi yang dapat mengganggu aktifitas dan memerlukan pengobatan. Dismenore ditandai dengan nyeri atau rasa sakit di daerah perut atau pinggul, nyeri haid yang bersifat kram dan berpusat pada perut bagian bawah. Nyeri kram yang terasa sebelum atau selama menstruasi bisa juga nyeri pada pantat. Rasa nyeri pada bagian dalam perut, mual, muntah, diare, pusing atau bahkan pingsan.

Untuk menghilangkan rasa sakit yang disebabkan oleh dismenore dapat dilakukan dengan menggunakan obat-obat golongan analgetik seperti aspirin, asam mefenamat, parasetamol, kofein, dan feminax, obat-obat merek dagang yang beredar di pasaran antara lain novalgin, ponstan, sering juga digunakan untuk mengurangi keluhan. Ada juga yang menggunakan obat tradisional seperti air daun sirih, daun pepaya, rimpang kunyit dan lain-lain. ${ }^{1}$

Sebagian besar perempuan yang mengalami dismenore sering menggunakan obat merek dagang yang berfungsi sebagai analgetik seperti asam mefenamat, ibu profen, aspirin, paracetamol, diklofenak, dan lain-lain. Secara umum efek samping obat analgetik tersebut adalah gangguan pada saluran cerna, seperti mual, muntah, dispepsia, diare, dan gejala iritasi lain terhadap mukosa lambung, serta eritema kulit dan nyeri pada kepala. ${ }^{1,3}$ Untuk itu ingin diketahui gambaran pengetahuan remaja putri terhadap dismenore dan cara menaggulanginya.

Banyak perempuan mengalami ketidaknyamanan fisik selama beberapa hari sebelum periode menstruasi mereka datang, ${ }^{4}$ kira-kira setengah dari seluruh perempuan menderita akibat dismenore (menstruasi yang menyakitkan). Nyeri itu sendiri dapat digambarkan dengan nyeri ringan, nyeri sedang dan nyeri berat hingga nyeri ini dapat diobati dengan obat obatan dismenore. ${ }^{5.6}$

\section{METODE}

Jenis penelitian ini adalah analitik prospektif, populasi penelitian adalah mahasiwi Stifarm Padang Angkatan 2013 dengan usia dibawah 19 tahun. Penelitian dilakukan pada bulan Desember 2013 dengan jumlah subjek penelitian 56 orang yang diambil dengan metode total sampling dengan criteria inklusi remaja putri, usia 16-19 tahun dan sudah pernah menstruasi. Pengambilan sampel dilakukan dengan menggunakan teknik simple random sampling yaitu pengambilan sampel secara acak sederhana dengan melakukan pengundian terhadap anggota populasi.

Jumlah atau besar sampel dalam penelitian ini diambil dengan menggunakan rumus sebagai berikut: $^{7}$

$$
\begin{aligned}
\mathrm{n} & =\frac{\mathrm{N}}{1+\mathrm{N}\left(\mathrm{d}^{2}\right)}=\frac{12 \mathrm{~g}}{1+12 \mathrm{~B}\left(0,1^{2}\right)} \\
& =56 \text { Orang }
\end{aligned}
$$

Keterangan :

$$
\begin{array}{ll}
\mathrm{N} & =\text { Besar populasi } \\
\mathrm{n} & =\text { Besar sampel } \\
\mathrm{d} & =\text { Ketetapan relatif }(10 \%)
\end{array}
$$


Dengan tingkat kepercayaan yang

dikehendaki sebesar $90 \%$ dan tingkat ketetapan relatif adalah 10\%. Maka jumlah sampel yang diperoleh dengan memakai rumus tersebut adalah sebanyak 56 org.

Menurut Arikunto, dapat diketahui dan diinterprestasikan dengan skala yaitu :

Tinggi (76 - $100 \%$ ); Cukup (56 - $75 \%$ ) dan Rendah $(<56 \%)^{8}$

Data-data hasil penelitian disajikan dalam bentuk tabel berupa persentase.

\section{HASIL DAN PEMBAHASAN}

Berdasarkan hasil pengisian kuesioner terhadap 56 orang responden diketahui Responden yang tahu dengan arti menstruasi (96,43\%), lama menstruasi (100\%), siklus menstruasi $(6,97 \%)$ dan hormon yang mempengaruhi menstruasi (23,21\%). Responden yang tahu dengan arti dismenore $(66,07 \%)$, usia yang sering mengalami dismenore $(100 \%$,$) kapan terjadinya dismenore (96,43 \%)$, bagian tubuh yang terasa sakit ketika dismenore $(82,14 \%)$, derajat dismenore $(71,14 \%)$, dismenore kuat $(96,43 \%)$ dan penyebab terjadinya dismenore secara berurut adalah $94,647 \%$.
Tabel 1. Gambaran pengetahuan responden terhadap dismenore

\begin{tabular}{|c|c|c|c|c|c|c|}
\hline \multirow{3}{*}{ No } & \multirow{3}{*}{ Kategori } & \multicolumn{4}{|c|}{ Jawaban Responden } & \multirow{3}{*}{$\begin{array}{c}\text { Jumlah } \\
\text { Respond } \\
\text { en }\end{array}$} \\
\hline & & \multicolumn{2}{|c|}{ Benar } & \multicolumn{2}{|c|}{ Salah } & \\
\hline & & Jumlah & $\%$ & Jumlah & $\%$ & \\
\hline 1 & Arti menstruasi & 54 & 96,43 & 2 & 3,57 & 56 \\
\hline 2 & $\begin{array}{l}\text { Lama terjadinya } \\
\text { menstruasi }\end{array}$ & 56 & 100 & 0 & 0 & 56 \\
\hline 3 & Siklus menstruasi & 13 & 23,21 & 43 & 76,79 & 56 \\
\hline 4 & $\begin{array}{l}\text { Hormone yang } \\
\text { mempengaruhi } \\
\text { siklus menstruasi }\end{array}$ & 13 & 23,21 & 43 & 76,79 & 56 \\
\hline 5 & Arti dismenorrhoe & 37 & 66,07 & 19 & 33,93 & 56 \\
\hline 6 & $\begin{array}{l}\text { Usia yang sering } \\
\text { menderita } \\
\text { dismenorrhoe }\end{array}$ & 56 & 100 & 0 & 0 & 56 \\
\hline 7 & $\begin{array}{l}\text { Kapan terjadinya } \\
\text { dismenorrhoe }\end{array}$ & 54 & 96,43 & 2 & 3,57 & 56 \\
\hline 8 & $\begin{array}{l}\text { Yang terasa sakit } \\
\text { ketika } \\
\text { dismenorrhoe }\end{array}$ & 46 & 82,14 & 10 & 17,86 & 56 \\
\hline 9 & $\begin{array}{l}\text { Derajat } \\
\text { dismenorrhoe }\end{array}$ & 40 & 71,14 & 16 & 28,86 & 56 \\
\hline 10 & $\begin{array}{l}\text { Dismenorrhoe } \\
\text { kuat }\end{array}$ & 54 & 96,43 & 2 & 3,57 & 56 \\
\hline 11 & $\begin{array}{l}\text { Penyabab } \\
\text { terjadinya } \\
\text { dismenorrhoe }\end{array}$ & 53 & 94,64 & 3 & 5,36 & 56 \\
\hline & Jumlah & & & & & 616 \\
\hline & $\%$ & & & & & 100 \\
\hline
\end{tabular}

Gambaran pengetahuan responden terhadap

Dismenore $\quad=\underline{476} \times 100 \%$

616

$=77,27 \%$ (Tinggi) 
Responden berpengetahuan tinggi tentang arti menstruasi $(96,43 \%)$ dan lama menstruasi (100\%) karena responden mengalami hal tersebut. Menstruasi merupakan suatu kondisi perubahan fisiologis dalam tubuh seorang perempuan yang terjadi secara berkala dan dialami setiap bulan secara rutin. ${ }^{9}$ Responden berpengetahuan rendah tentang siklus menstruasi dan hormon yang mempengaruhi menstruasi (23,21\%) karena hal tersebut berkaitan dengan ilmu pengetahuan.

Responden berpengetahuan cukup tentang arti dismenore $(66,07 \%)$ dan derajat dismenore $(71,14 \%)$ karena dismenore merupakan istilah yang digunakan di bidang medis dan klasifikasi derajat dismenore yang didasarkan pada derajat nyeri hanya digunakan dalam istilah kesehatan. Responden berpengetahuan tinggi tentang usia yang sering mengalami dismenore (100\%), kapan terjadinya dismenore $(96,43 \%)$, bagian tubuh yang terasa sakit ketika dismenore (82,14\%), dismenore kuat $(96,43 \%)$ dan penyebab terjadinya dismenore $(94,64 \%)$ karena responden mengalami hal tersebut. Hampir setengah dari seluruh perempuan mengalami ketidaknyamanan fisik selama menstruasi yang disebabkan oleh dismenore. ${ }^{10}$ Nyeri dirasakan di daerah perut bagian bawah dan dapat menjalar ke punggung ataupun paha bagian dalam yang terkadang dapat menyebabkan penderita tidak berdaya dalam menahan nyeri tersebut. $^{6}$

Tindakan yang dilakukan responden ketika dismenore yaitu tindakan non farmakologi $(17,86 \%)$ dan tindakan farmakologi (82,14\%). Diketahui responden melakukan tindakan nonfarmakologi dalam menanggulangi dismenore disebabkan karena tindakan tersebut dapat dilalukan langsung ketika responden merasakan dismenore. Kurang dari 25\% masyarakat Indonesia yang berobat ke dokter untuk mengobati dismenore. Lebih dari $65 \%$ wanita memanfaatkan pengobatan sendiri untuk menanggulangi dismenore seperti menggunakan obat tradisional ataupun obat yang dijual bebas. ${ }^{4}$

Nyeri haid sering terjadi pada perempuan usia muda, karena belum mencapai kematangan biologis (khususnya kematangan alat reproduksi yaitu pertumbuhan endometrium masih belum sempurna) dan psikologis. Dismenore primer biasanya mulai pada saat siklus telah menjadi ovulasi dalam tahun-tahun usia reproduksi dan siklus reguler. Puncak umur insiden perempuan yang mengalami dismenore adalah 20 sampai 24 tahun. $^{11}$ Frekuensi nyeri akan menurun sesuai dengan bertambahnya usia. Hal ini diduga terjadi karena adanya kemunduran saraf rahim akibat penuaan.

Tindakan nonfarmakologi yang dilakukan responden untuk menanggulangi dismenore yaitu tidur (70\%), dipijat (20\%) dan refreshing 10\%.

Untuk mengurangi atau menghilangkan nyeri ketika menstruasi responden lebih cenderung tidur dari pada dipijat, karena ada sebagian orang yang tidak suka dipijat. $^{11}$

Obat tradisional yang digunakan responden untuk menanggulangi dismenore yaitu daun sirih (67\%), rimpang kunyit (20\%) dan daun papaya (13\%). Hasil penelitian menunjukan bahwa kunyit berfungsi dalam mengurangi nyeri dismenore pada remaja putri dan penurunan tingkat nyeri terjadi rata-rata setelah 15 menit perlakuan. ${ }^{11}$

Tabel 2.Persentase Responden Terhadap Tindakan Yang Dilakukan Ketika Dismenore

\begin{tabular}{|c|c|c|c|c|c|}
\hline Tindakan & $\%$ & $\begin{array}{l}\text { Tindakan } \\
\text { Obat }\end{array}$ & $\%$ & $\begin{array}{l}\text { Tindakan } \\
\text { Obat }\end{array}$ & $\%$ \\
\hline Non & 17,86 & Tidur & 70 & & \\
\hline \multirow[t]{2}{*}{ farmakologi } & & Pijat & 20 & & \\
\hline & & Refresing & 10 & & \\
\hline \multirow[t]{9}{*}{ Farmakologi } & 82,14 & Obat & 32,16 & Sirih & 67 \\
\hline & & tradiosional & & Kunyit & 20 \\
\hline & & (OT) & & Pepaya & 13 \\
\hline & & Obat jadi & 54,35 & OJ-1(F) & 20 \\
\hline & & (OJ) & & OJ-2(K) & 40 \\
\hline & & & & OJ-3(M) & 28 \\
\hline & & & & OJ-4(PL) & 8 \\
\hline & & & & OJ-5(PX) & 4 \\
\hline & & Gab OT-OJ & 13,04 & & \\
\hline
\end{tabular}

Obat yang digunakan responden untuk menanggulangi dismenore yaitu obat tradisional $(32,61 \%)$, obat jadi $(54,35 \%)$ dan kedua obat tersebut $13,04 \%$.

Obat jadi yang digunakan responden untuk menanggulangi dismenore yaitu OJ-1 (20\%), OJ-2 (40\%), OJ-3 (28\%), OJ-4 (8\%) dan OJ-5 (4\%).

Penderita dismenore cenderung memilih obat yang tersedia dan beredar banyak dipasaran baik di Apotik, toko obat ataupun warung-warung. ${ }^{2}$

Apabila nyeri cukup mengganggu dapat 
mengkonsumsi obat- obatan analgetik yang dijual secara bebas tetapi harus memperhatikan efek samping terhadap lambung. ${ }^{1}$

Efek samping obat jadi yang digunakan responden yaitu mengantuk (56,52\%), pusing dan mual $(32,61 \%)$, mengantuk yang disertai pusing dan mual $(10,87 \%)$.

Tabel 3. Persentase Responden Terhadap Efek Samping Obat Jadi yang Digunakan

\begin{tabular}{cll} 
Efek samping obat jadi yang digunakan Ketika & \\
& Dismenore (\%) & \\
\hline Mengantuk & $\begin{array}{l}\text { Pusing dan } \\
\text { mual }\end{array}$ & $\begin{array}{l}\text { Mengantuk } \\
\text { yang disertai } \\
\text { pusing dan } \\
\text { mual }\end{array}$ \\
\hline 56,52 & 32,61 & 10,87
\end{tabular}

Alasan pemilihan obat yang digunakan responden untuk menangggulangi dismenore pada umumnya disebabkan oleh karena obat tersebut cepat menghilangkan nyeri (97,83\%).

Tabel 4.Persentase Responden Terhadap Alasan Pemilihan Obat

\begin{tabular}{lll}
\hline \multicolumn{2}{c}{ Alasan Pemilihan Obat Ketika Dismenore (\%) } \\
\hline $\begin{array}{l}\text { Diberi tahu } \\
\text { teman }\end{array}$ & $\begin{array}{l}\text { Harganya } \\
\text { murah }\end{array}$ & $\begin{array}{l}\text { Cepat } \\
\text { menghilangkan } \\
\end{array}$ \\
& 0 & nyeri \\
\hline 2,17 & 07,83
\end{tabular}

\section{KESIMPULAN}

Berdasarkan data yang diperoleh melalui pengisian kuesioner dapat ditarik kesimpulan bahwa :

1. Gambaran pengetahuan remaja putri terhadap dismenore termasuk tinggi.

2. Tindakan utama dalam menanggulangi dismenore di kalangan remaja putri adalah tindakan non farmakologi $(17,86 \%)$ dengan cara terbanyak adalah tidur (70\%), Tindakan secara Farmakologi $(82,14 \%)$ dengan menggunakan obat tradisional $(32,61 \%)$ kebanyakan menggunakan daun sirih (67\%). Menggunakan Obat Jadi (54,35\%) kebanyakan mereka menggunakan OJ-2 (40\%),

3. Efek samping yang paling banyak dirasakan setelah meminum obat pereda nyeri haid adalah mengantuk (56,52\%).

4. Dasar pemilihan obat dalam menanggulangi dismenore oleh remaja putri adalah karena obat tersebut cepat menghilangkan nyeri $(97,83 \%)$.

\section{DAFTAR PUSTAKA}

1. Wiknjosastro, Hanifa .Ilmu Kandungan. Yayasan Bina Pustaka Sarwono Prawiroharjo: Jakarta;2007.

2. Dito, Anrogo. Cara Jitu Mengatasi Nyeri haid, Yogyakarta;2011

3. Feinman Jane. Segala Hal Yang Bersangkutan Tentang Menstruasi, PT Primedia Pustaka, Jakarta;2003.

4. Darmansjah I, Dasar Toksikologi Dalam Farmakologi dan Terapi, Jakarta: Bagian Farmakologi FKUI, Edisi 5;2012.

5. Dawood, my, : Dismenore In : Scianra JJ. Gynaecology and Obstretric, reviset edition, Philadelphia, J.B Lippin cott company. 2006, 108(2):428-41.

6. Benson, Ralph C \& Pernoll, MartinL., Berbagai Kelainan dan komplikasi Menstruasi. Dalam : Buku saku obstetric dan ginekologi. Jakarta, 2009.

7. Notoatmodjo Soekijo, Metodologi Penelitian, Rineka Cipta Jakarta;2002.

8. Arikunto, S, Prosedur Penelitian : Suatu Pendekatan Praktek, edisi v, Jakarta: Rineka Cipta, 2004

9. Elvira, D., Sylvia, Sindrom Pra Menstruasi,Jakarta: FKUI.;2010.

10. Parson L, Sommer Sc. Gynaecology, Second Edition, W. B. Saunders Company, Philadelalaphia,;1998.

11. Galya, Junizar, Sulianingsih, Dharma K. Widya, Pengobatan Dismenore Secara Akupuntur, Jakara: Cermin Dunia Kedokteran;2001. 